\section{EMBRYRIDDLE}

Aeronautical University

SCHOLARLY COMMONS
Journal of Aviation/Aerospace

Education \& Research

Volume 15

Number 1 JAAER Fall 2005

Article 1

Fall 2005

\title{
An Assessment of Intensive/Weekend Teaching Format of Aviation Education: A Case of Aviation Law
}

Chien-tsung Lu

Follow this and additional works at: https://commons.erau.edu/jaaer

\section{Scholarly Commons Citation}

Lu, C. (2005). An Assessment of Intensive/Weekend Teaching Format of Aviation Education: A Case of Aviation Law. Journal of Aviation/Aerospace Education \& Research, 15(1). https://doi.org/10.15394/ jaaer.2005.1505

This Article is brought to you for free and open access by the Journals at Scholarly Commons. It has been accepted for inclusion in Journal of Aviation/Aerospace Education \& Research by an authorized administrator of Scholarly Commons. For more information, please contact commons@erau.edu. 


\title{
AN ASSESSMENT OF INTENSIVE/WEEKEND TEACHING FORMAT OF AVIATION EDUCATION: A CASE OF AVIATION LAW
}

\author{
Chien-tsung Lu
}

\begin{abstract}
Although most universities in the United States (U.S.) have launched off-campus education for working adults, the quality of such an educational format remains skeptical to many educators who exchange knowledge mainly via on-campus lecture means (Elliott et al, 1978; Swenson, 2003 Spring). In order to further examine academic performance based on such a non-traditional channel, the rigor and integrity of off-campus education should be investigated (Karwin, 1973). This study sought to evaluate the learning outcome of off-campus aviation education currently using intensive/weekend seminar format. Meanwhile, the main goals of this study also include the discovery of possible pedagogical gaps to continuously enhance off-campus teaching. Focus group was utilized as the research methodology. Purposive sampling was applied containing two groups of students, one on-campus and off-campus for another, recruited from aviation law class. Both qualitative and quantitative data were collected and analyzed. The result showed flexibility of class study and convenient location of classroom were the two most attractive factors adult learners consider. In addition to opposing to a fully Internet-based aviation education, off-campus students' comments helped the researcher reveal specific pedagogical deficiencies that need to be reviewed for validating future educational service.
\end{abstract}

\section{INTRODUCTION}

Most universities were initially designed to serve students who were able to attend classes on campus. Since the $1970 \mathrm{~s}$, an increasing population of working adults learners who seek to return to college, maintain a full-time working status, and complete their degree without routinely sitting in classroom has thrown a pedagogical challenge to the higher education system in the United States (U.S.) (Elliottt et al., 1978; Husson \& Kennedy, 2003). From the university's standpoint, how to accommodate those eager adult learners requires a special class design (Mott, 2000 Summer). To this end, intensive weekend classes, television broadcasting programs, and most currently, online Internet disciplines were provided (Scott, 2003). As an important partner of the higher education system in the U.S., Central Missouri State University (CMSU) is no exception to this observation. By creating satellite campuses/learning centers (Karwin, 1973) surrounding its main campus in Warrensburg, Missouri, the Department of Aviation at
CMSU currently applies weekend intensive format conducting senior and graduate-level classes such as aviation law, airport planning and management, air transportation, system safety, and most other classes leading to the completion of undergraduate and aviation safety master degrees. Because there is no one-size-fits-all teaching format (Pratt, 2002), the aviation department also provides regular lectures to students by hiring adjunct faculties teaching at one satellite campus. In order to discover the current status of learning and teaching quality, the outcome of CMSU's intensive format education should be measured. By doing so, this study could help aviation educators further enhance class rigor and integrity. Furthermore, based on the results of this study, the aviation department can better serve non-traditional students and proactively maintain the credential requirements from accreditation agencies focusing on teaching and learning outcomes. 


\section{LITERATURE REVIEW}

"Learning is celebrated and seen as a vehicle for citizens to build more life-sustaining places to live, work, and enjoy" (Stein \& Imel, 2003, p.93).

In the aviation industry, proactive adult learners, who dwell in the changing aviation community, have consistently encountered problems, issues, and challenges associated with their daily works that immediately require new skills and knowledge to deal with challenges. In order to elevate competitive ability and inventory a better workforce, many industries seek to promote employees' capability by motivating them to pursue more education (Husson \& Kennedy, 2003).

Educational researchers have conducted numerous researches in relation to teaching enhancement. Those researchers include Elliott and her research associates, Herrmann, Fox, and Boyl, Gadlbow, Wlodkowski and Westover, Scott, Phillips and Kelly, Caskey, and Husson and Kennedy. Elliott and her research associates (1978) remarked that the primary reasons for adult learners to participate in off-campus education were: 1) inflexible working schedule, 2) enhancement of personal skills, 3) personal interest, and 4) continuing needs of community service-oriented education. As the chairman of the Missouri Department of Higher Education, Elliott concluded that the quality of faculty, a well-designed class, a smoothly-run administrative unit, a sufficient source of student service, and a complete set of policies were essential to a successful off-campus education.

Another distance learning study conducted by Herrmann, Fox, and Boyl in 2000 revealed that although the current technology is able to provide instructors appropriate tools for instructing, "how teachers adopt learning technologies is complex" (Hermann, Fox, \& Boyl, 2000, p.43). As a result, faculties may choose to avoid learning new skills themselves such as Internet system. Therefore, the so-called truly user-friendly environment for adult learners remains controversial if instructors could not train themselves well. Moreover, one of the most critical but unexpected difficulties of distance leaming via Internet is that many adult learners lack technological capabilities or the equivalent devises, such as online skills and computers with which they should initially equipped (Herrmann, Fox, \& Boyl, 2000). In addition to the aforementioned difficulties, most adult learners already have burdens of maintaining their full-time job, family relationship, and social life. They highly cherish their time and must utilize it in an extremely efficient fashion (Herrmann, Fox, \& Boyl, 2000).

Gadlbow (2003) remarked that those who cannot meet class schedules on campus due to time or space barriers are now encouraged to learn over the weekend and in their free time (Gadbow, 2003). Rather than downgrading the quality of education in relation to intensive format, educational researchers (Scott \& Conrad, 1992; Caskey, 1994; Wlodkowski \& Westover, 1999) had discovered that "intensive courses yield equivalence, and sometimes, superior learning outcomes when compared to matched traditional-length courses" (Scott, 2003, p.29).

Most recently, in Scott's study, some universities offer intensive courses to students in addition to the traditional version of higher education. Regardless of the sporadic concerns about rigor and quality of the program, from the viewpoint of pedagogic researchers, intensive format of education is popular and welcomed by the adult learners (Scott, 2003). As the result of Scott's research (2003), students remarked that the characteristics and advantages pertaining to intensive format courses are: 1) Focused learning, 2) In-depth discussion, 3) Memorable learning experience, 4) Better learning atmosphere, and 5) Better performance.

Phillips and Kelly (2000) noted that continuous consultation and advice pertaining to non-traditional learners plays a crucial role in determining learning performance, as well as directly deciding the success of an off-campus education. In reality, even though the off-campus students cannot attend traditional on-campus classes, from time to time, they would still like to communicate with their instructor in person.

Unfortunately, although the amount of distance education has been increased over the past decade (Cervero, 2000 Summer), many working adults still face barriers in terms of available sources and opportunities impeding them from receiving more education. For instance, Cervero (2000 Summer) argued that there are three critical components associated with continuous professional education (CPE), which educational researchers need to solve before evolving to another stage of the off campus education. First, the purpose of continuing education for working adults should be clarified (objectives of the program). Second, the pool of prospective students should be identified (understanding of the needs of students). And third, a qualified provider of continuing education should be available (an effective and efficient educating mechanism).

Husson and Kennedy (2003) further echoed Cervero's arguments in their article and specifically dictated the essential factors of a successful intensive-format 
education for adult learners. These factors are: 1) adult learner-oriented (environment), 2) high rigor of the education (quality), and 3) program accessibility (flexible schedule) (Husson \& Kennedy, 2003), from which class coordinators/designers could detect the weakness, revise the program, and strengthen the curriculum of intensive study. Our Aviation Program

Many collegiate aviation partners in the U.S. have provided distance education for years. Yet, to date, a specific measuring tool regarding the effectiveness of the intensive format aviation education provided to adult learners is hard to find in aviation area. In order to satisfy increasingly needed adult learners in the Midwest, Central Missouri State University has been encouraging all academic departments to initiate distance education and also maintain a competitive quality. Because students' comments/feedbacks would directly benefit service providers, aviation faculties should periodically evaluate their teaching quality of aviation programs that adopt intensive weekend format. By revising the quality of intensive weekend classes, the department is able to locate educational deficiencies for future enhancement. It also would be less effective for an educational institute to elevate its program without evaluating students' needs beforehand.

\section{Research Questions}

Regardless of the sporadic comments from former aviation students, the aviation department of CMSU had not performed an official report regarding this issue. As a result, the quality (students' satisfaction regarding off-campus education) of the aviation program and the needs of prospective students were unclear. For future student recruitment and program enhancement, the author defined research questions as follows:

1. Recruitment Approach: What are the reasons for adult learners to take off-campus aviation class while working as a fulltime employee?

2. Pedagogical Approach: What can be done to enhance off-campus education regarding teaching and learning perspectives?

\section{Research Objectives}

This study focused on the students who took aviation law class in Fall 2003. The objectives of this study are threefold: 1) perceiving the needs of off-campus aviation students, 2) locating the learning gaps and enhancing instructor's teaching quality, and 3) discovering the practicality of a totally Internet-based off-campus aviation education. To this end, the author implemented three mainstreams of inquiry.

Significance
This research primarily sought to evaluate the educational performance, because there is no study of the learning outcome in terms of intensive format aviation education in the Department of Aviation at CMSU. This study could fulfill the future requirements based on the information provided by off-campus students for the purpose of marketing aviation education. This study is also important to aviation educators and academic entities that provide off-campus classes.

\section{METHODOLOGY}

Two groups of aviation law students of Fall semester 2003 had been consulted and were willing to voluntarily participate in this study in 2004. A pilot-tested questionnaire was delivered to participants for discussion and analytic results were reviewed. The descriptive statistics of learning outcome was recorded and measured by using MINITAB. Qualitative data was retrieved through focus groups discussion followed by personal interviews based on necessity.

\section{Focus Group Method}

Focus group techniques were adopted in this study. Morgan (1993) remarked that focus group "takes advantage of group dynamics to produce new and additional data" (p. 32). Robinson (1999) echoed and stated that a focus group is "an in-depth, open-ended group discussion of 1-2 hours' duration that explores a specific set of issues on a predefined and limited topic" (p. 906). Most importantly, conducting a focus group discussion does not attempt to gain consensus or agreement on the topic of discussion (Robinson, 1999, p. 907). Rather, the focus group method embraces free-flowing dialogue not constrained by preconceived recognitions and group dynamics are inherent (Barbour \& Kitzinger, 1999). The focus group techniques allow researchers to unveil underlying assumptions that were not apparent in most quantitative types of researches (Morgan, 1993). This study utilized focus group discussion as a kind of brainstorming session for data collection.

\section{Participants/Key Informants}

Purposive sampling technique was utilized due to the nature of the research setting of this study. Purposive sampling focuses on the heuristic exploration and in-depth interview of targeted key informants who possess a direct connection to various essential and valid data resources (Babbie, 1998; Bellenger, Bernhardt, \& Goldstucker, 1976; Maykut \& Morehouse, 1994). There were fourteen (14) offcampus students voluntarily participated in the study and selected as key informants.

\section{Instrument}

This study used a pilot-tested questionnaire (see Appendix) as well as tape recorder for data collecting when 
permitted by participants. Pilot testing of the questionnaire was done by selected volunteers containing aviation educators and students. Qualitative data were managed by using EZ Text software. The comparison of learning outcomes was calculated based on the final grade earned by each student. The data collection period was between January $27^{\text {th }}$ and March $18^{\text {th }}, 2004$ after the Fall semester of 2003 was ended. Thus, research participants did discuss their assigned topics within a pressure-free environment.

\section{Reliability and Validity of the Study}

Fowler (1993 \& 1995) and Charlton (1996) outlined four consequent steps for qualitative researchers in constructing a new survey questionnaire with the highest level of reliability. They are: 1) the format design based on the purpose of the study, 2) the determination of the response scale and its associated descriptor set, 3) the construct of proper wordings (short, relevant, and easy to read), and 4) a review and pilot-test of the questionnaire by a review board. Specifically, pilot-testing the questionnaire will help gain external validity. As stressed further by Oppenheim (1996), questionnaires should be tested, revised, and adapted "after many abortive test flights" until researchers can ensure that the questionnaires "can do the job for which they are needed" (p.47). This validity review has been, to some extent, obligatorily utilized by researchers in various disciplines such as aeronautics (Johnson, 1997), policy analysis (Hilvitz, 2000), and education (Ray, 2001), and it helps researchers to eliminate irrelevant ideas, redefine questions, and comprehensively validate interviews. The questionnaire was pilot-tested and its revisions were completed in December 2003.

\section{Ethical Compliance}

Ethical concerns were precisely complied. According to codes of ethics, the provided information will remain extremely confidential meaning no collected information were treated or distributed beyond specifically identified individuals or organizations (Maykut \& Morehouse, 1994; Maxwell, 1996). Collected data were coded without releasing participants' names, jobs or any sensitive materials or alike. In addition, the results emanating from this study were reported in general terms without reference to particular participants. For only research purpose, participants' comments remained anonymous (Creswell, 1998; Maykut \& Morehouse, 1994; Maxwell, 1996). Finally, the research approval (waiver) was gained on January $20^{\text {th }}, 2004$ after having been reviewed by the CMSU's Institutional Review Board (IRB).

\section{FINDINGS}

This section analyzed comments and feedbacks from participants and yielded findings. According to findings, there were seven graduate and seven undergraduate students in the St. Louis class. The overall quality of the aviation law class was between excellent and good. Most off-campus students were new students to the aviation program. In addition, most students showed that the class arrangement met their schedule and they had learned what they expected to learn (See Table 1). 
Table 1

Overall Information of Informants

\begin{tabular}{|l|l|l|l|l|l|}
\hline Age $^{1}$ & Status & $\begin{array}{l}\text { Class } \\
\text { taken }\end{array}$ & Schedule & Quality & Expectation \\
\hline Category 4 & Graduate & 5 & Yes & Excellent & 9 \\
\hline Category 1 & Graduate & 5 & Yes & Good & 9 \\
\hline Category 3 & Graduate & 2 & Yes & Excellent & 10 \\
\hline Category 1 & Undergraduate & 1 & Yes & Good & 9 \\
\hline Category 4 & Graduate & 1 & Yes & Good & 9 \\
\hline Category 1 & Undergraduate & 1 & Yes & Excellent & 9 \\
\hline Category 1 & Graduate & 5 & Yes & Good & 10 \\
\hline Category 3 & Graduate & 2 & Yes & Excellent & 10 \\
\hline Category 1 & Undergraduate & 1 & Yes & Good & 9 \\
\hline Category 4 & Undergraduate & 5 & Yes & Excellent & 9 \\
\hline Category 1 & Undergraduate & 1 & Yes & Excellent & 9 \\
\hline Category 1 & Graduate & 5 & Yes & Good & 9 \\
\hline Category 1 & Undergraduate & 1 & Yes & Good & 9 \\
\hline Category 4 & Undergraduate & 1 & Yes & Good & 9 \\
\hline
\end{tabular}

Note: ' Category 1 (20-25 years), Category 2 (26-35 years), Category 3 (36-45 years), Category 4 (45 and above). ${ }^{2}$ Meeting student's expectation? Likert scale 1 (Strongly Disagree) and 10 (Strongly Agree)

\section{Section I Close-ended Questions}

Table 2 further indicated that most off-campus students regarded tests, chapter assignments, supplemental handouts, case review, research paper, presentation, group discussion, and roleplaying moot court as helpful in understanding and learning aviation laws. Yet the projects of reporting risky activities via NASA's Aviation Safety Reporting Program (ASRP) and commenting on selected FAA's Notice of Proposed Rulemakings (NPRMs) did not show importance. 
An Assessment of Intensive Teaching

Table 2

Effectiveness of Learning Regarding Class Contents

\begin{tabular}{|c|c|c|c|c|c|c|c|c|c|}
\hline Test & $\begin{array}{c}\text { Assign } \\
\text { Ments }\end{array}$ & Handout & $\begin{array}{c}\text { Case } \\
\text { review }\end{array}$ & $\begin{array}{c}\text { Research } \\
\text { Paper }\end{array}$ & $\begin{array}{c}\text { Presen } \\
\text { tation }\end{array}$ & ASRP & NPRM & Discussion & $\begin{array}{c}\text { Moot } \\
\text { Court }\end{array}$ \\
\hline Yes & Yes & Yes & Yes & Yes & Yes & No & Yes & Yes & Yes \\
\hline Yes & Yes & Yes & Yes & Yes & Yes & n/a & Yes & Yes & Yes \\
\hline Yes & Yes & Yes & Yes & n/a & Yes & Yes & Yes & Yes & Yes \\
\hline No & No & Yes & No & n/a & No & No & No & Yes & Yes \\
\hline Yes & Yes & No & No & Yes & No & No & No & Yes & No \\
\hline Yes & Yes & Yes & Yes & No & Yes & No & No & Yes & Yes \\
\hline Yes & Yes & Yes & Yes & Yes & Yes & n/a & Yes & Yes & Yes \\
\hline Yes & Yes & Yes & Yes & n/a & Yes & Yes & Yes & Yes & Yes \\
\hline No & No & Yes & No & n/a & No & No & No & Yes & Yes \\
\hline Yes & Yes & Yes & Yes & Yes & Yes & No & Yes & Yes & Yes \\
\hline Yes & Yes & Yes & Yes & n/a & Yes & No & No & Yes & Yes \\
\hline Yes & Yes & Yes & Yes & Yes & Yes & n/a & Yes & Yes & Yes \\
\hline No & No & Yes & No & n/a & No & No & No & Yes & Yes \\
\hline Yes & Yes & No & No & Yes & No & No & No & Yes & No \\
\hline
\end{tabular}




\section{Section II Synthetic Summary of the Discussed Open- ended Questions}

Based on collect data from participants, the purpose for offcampus students to study while working fulltime or part time included:

1. Personal capability

2. Degree completion

3. Knowledge needed

The rationale for students to take off-campus classes based on weekend intensive format included:

1. Class availability

2. Flexibility schedule

3. Convenience location

The comments on enhancing weekend intensive education included:

1. More examples reflecting the current industry's facts

2. More guest speakers from the industry

3. More mock trial practices

Regarding the value of a totally Internet-based aviation (law) class, the comments of off-campus students included:

1. Internet training required beforehand

2. A one-on-one interaction is essential

3. Good for those who could not participate in intensive weekend classes

4. May not meet the schedule if not available on weekends

Regarding the learning environment for off-campus students based on a fully Internet-based education, the comments from students supporting Internet-based class included:

1. Need a reliable and fast Internet facility

2. A simple and straightforward design

3. Maintaining effective and efficient communications

On the contrary, those who did not support an Internet-based aviation class stated:

1. Lack of quality

2. Lack of group discussions and personal interaction

\section{DISCUSSION}

Regarding the content of aviation law, ASRS and NPRM both did not show the importance according to most comments from off-campus students. This finding either indicates that the instructor did not cover the materials well or students did not perceive the criticality of ASRS and NPRM in relation to their future aviation career.

Regarding the purpose for the adult learners to take class while maintaining a fulltime workload, one informant simply replied that returning to the university is " to get my degree" while the other informant highlighted that "This degree will provide the tools I need to do my work and possibly do some consulting." The other stated that he was "preparing for future job reduction in the industry." The analyzed data revealed that enhancing personal capability, degree completion, and expanding knowledge were the three most addressed reasons showing why adult learners return to school and take off-campus classes.

The rationale for students to take off-campus classes based on weekend intensive format included time availability, schedule flexibility, and travel convenience. As one informant stated, "it is easy to schedule according to my lifestyle." Another informant remarked that "it gives me more time on materials and job requirement." This finding implied that the aviation department must satisfy students' flexible schedules if we want to expand off-campus programs by means other than intensive format.

Regarding the question asking comments on enhancing the current weekend intensive format education, research informants suggested that the instructor should provide more examples reflecting the current industry's facts. Also, guest speakers from the industry should be invited and more mock trial practices should be conducted. One informant stated that the class should be continued, further explored and updated so as to "reflect the current industry trend." Another informant replied that the class should "continue to use people from diverse and necessary fields in aviation." As a matter of fact, this finding showed that off-campus students would like to obtain real-world experiences that can be applied to their current career. One informant further suggested a "more hands-on participation" aviation law class. This is to say that the instructor should conduct more mock trials, which would give students a platform to periodically utilize theories they have learned in class.

Regarding the value of a totally Internet-based aviation class, most students did not support a fully Internetbased aviation law class. Their concerns include: "it takes the personal interaction out of class," "there must be one-onone interaction," "need a reliable and fast Internet facility," and "I am not familiar with Internet techniques." This finding indicated that off-campus students did require feedbacks from the instructor in a timely manner. Lack of Internet training was another concern. On the contrary, those who supported fully Internet-based classes suggested that the class format should be "simple, straightforward (no fancy design), and easy to follow instructions." Instructor should maintain "effective and efficient communications" 
with students. On informant replied that "it is a golden opportunity for the university to expand its program." Thus, if the aviation department would like to conduct fully Internet-based classes, two crucial issues should be addressed beforehand. First, a mechanism to promptly answer students' questions, clarify their confusions, and involve group discussions is essential. Second, regarding the learning environment based on a fully Internet-based education, a compatible tool (computer, Internet provider, etc.) must be available.

Furthermore, a basic evaluation of participants' final grades revealed that off-campus students performed better (average $=92.17$ ) than on-campus students (average = 89.51) under an identical teaching platform such as the same teaching materials, projects, assignments, and examinations across St Louis (intensive format) and Warrensburg classes (traditional format).

Pedagogical Model

Based on the findings and discussion aforementioned, a model summarizing the study could be shown by the follow schematic chart (See Figure 1).

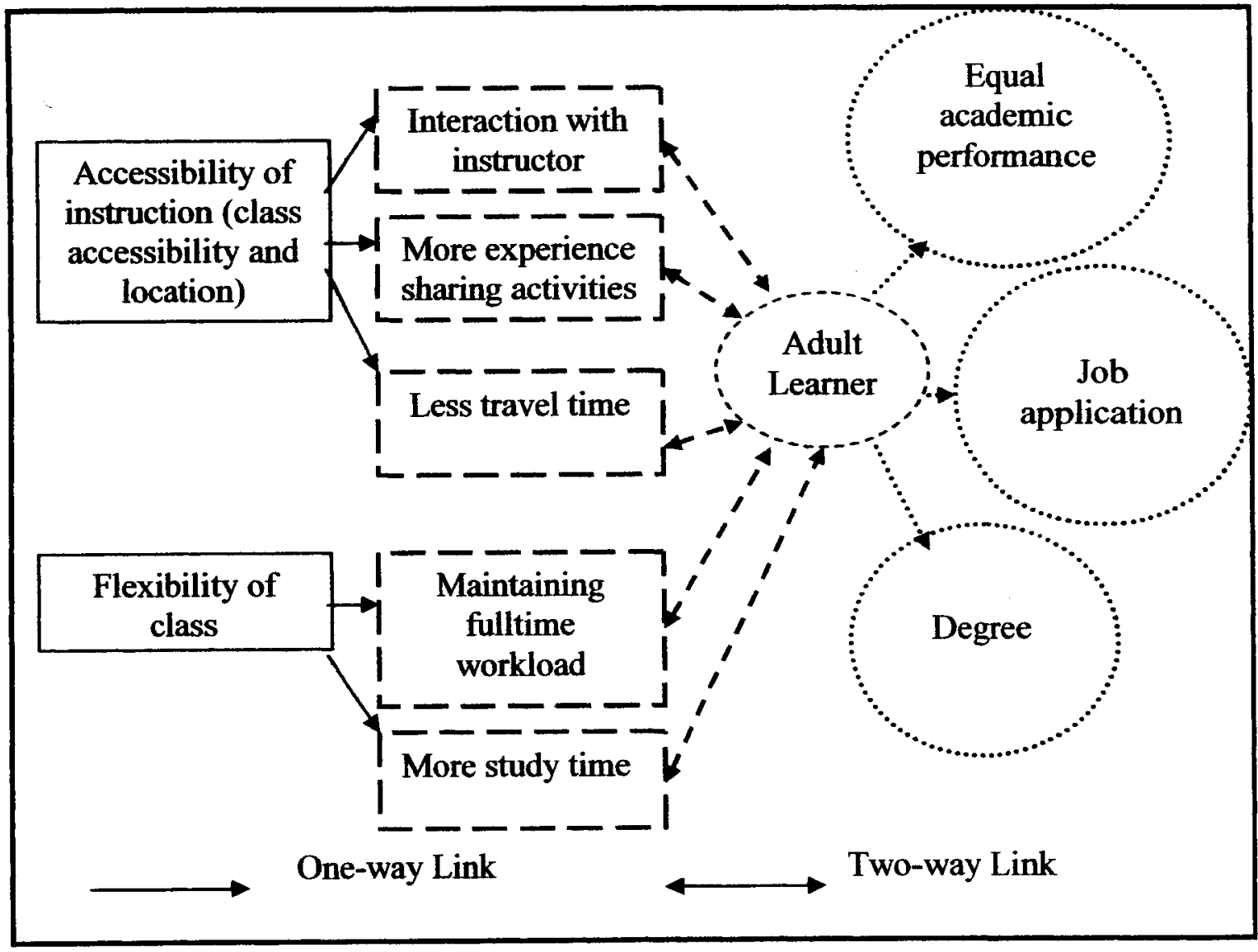

Figure 1. A Causal Model of Adult Learning in Aviation Education - Intensive Format 


\section{CONCLUSION}

Many adult learners are returning to universities for different reasons such as receiving most current knowledge, rejuvenating personal working skills, or completing a higher degree. Yet, being a full-time worker and participating in traditional on-campus classes simultaneously do not quite fit into their inflexible schedule. And to some extent, the requirement of attending class on campus was a significant drawback that discourages them from receiving more needed education. Because of the great scope of learning flexibility regarding off-campus education, the problems associated with off-campus students' fixed working schedule can be solved. Yet from the university's viewpoint, while offering off-campus education, the quality of such a service should also be maintained.

To accomplish the determined goals, this study: 1) Identified marketing factors for off-campus education, 2) Discovered teaching/learning deficiency(-ies) related to offcampus aviation law class (for teaching enhancement), 3) Compared the overall achievement between on-campus and off-campus students regarding aviation law class (for closing learning gaps between on-campus and off-campus education), and 4) obtained an important comment regarding the applicability of Internet aviation education.

In this study, while most off-campus students did not recognize the importance of ASRS, which may issue liability-immunity and could counteract the FAA's enforcement action; and NPRM, which is critical in aviation rulemaking, the instructor may need to revise class syllabi by providing more examples and cases to students showing the essentiality of these two critical pedagogical contents in aviation law. In addition, a roleplaying activity related to Aviation Rulemaking Advisory Committee (ARAC) could further help students understand the importance of NPRM in the FAA's rulemaking process.

Finally, the results showed that off-campus adult learners prefer intensive format education instead of a fully Internet-based education. It was mainly due to students' concern of lacking teacher-student interactions, efficient communications, and real-time problem solving. This is still true even though off-campus students would like to complete their degree, gain more knowledge, and sharpen their working skills when needed. To resolve this problem, the aviation department may implement a transactional teaching model, a dyad of Internet and in-class/off-campus lectures. That is, the instructor could apply the Blackboard system as a supplemental tool to maintain an efficient and effective communication to their off-campus students. By doing so, the instructor could ratify or, at least, measure the applicability of an Internet-based aviation education for future references. Furthermore, telephone communication is also useful and should be always available to students who need assistance from their instructor. Between two weekend seminars, normally four to five weeks, the Blackboard system could help provide class information, disseminate announcements, and sometimes give quizzes to students that would help keep their learning on a regular basis with class flexibility intact. For the future full implementation of Internet-based education, technological development should be available, for both user's and provider's end.

\section{FUTURE STUDY}

The research informants of this study were recruited from aviation law class both on-campus and off-campus. As mentioned earlier, the department of aviation provides many aviation classes such as Aviation System Safety, International Aviation, Corporate Aviation, and etc. on a rotating basis among its satellite campuses. Further investigation and comparison regarding students' comments of all intensive weekend classes is essential. A long-term research plan should be scheduled and implemented.

Chien-tsung Lu, Ph.D., is assistant professor at Department of Aviation at Central Missouri State University. He is an FAA certified technician and FCC licensee. His research and teaching interests are in the areas of air transportation policy, system safety, aviation safety, airline operation, and maintenance management. 


\section{REFERENCES}

Babbie, E. (1998). The practice of social research $\left(8^{\text {th }}\right.$ ed.). Belmont, CA: Wadsworth.

Bellenger, D. N., Bernhardt, K. L., \& Goldstucker, J. L. (1976). Qualitative research in marketing. Chicago, IL: American Marketing Association.

Barbour, R.S. \& Kitzinger, J. (Eds.). (1999). Developing focus group research. Thousand Oaks, CA: Sage.

Caskey, S.R. (1994). Leaming outcomes in intensive course. Journal of Continuing Higher Education, 42(2), 23-27

Cervero, R.M. (2000 Summer). Trends and issues in continuing professional education. In V. W. Mott and B. J. Daley (Ed.), Chartering A Course for Continuing Professional Education: Reframing Professional Practice (pp.1-12). San Francisco, CA: Jossey-Bass.

Charlton, S. G. (1996). Questionnaire techniques for test and evaluation. In T. G. O'Brien \& S. G. Charlton (Eds.), Handbook of human factors testing and evaluation (pp. 81-99). Mahwah, NJ: Lawrence Erlbaum.

Creswell, J. W. (1998). Qualitative inquiry and research design: Choosing among five traditions. Thousand Oaks, CA: Sage.

Fowler, F. J., Jr. (1993). Survey research methods ( $2^{\text {nd }}$ ed.). Newbury Park, CA: Sage

Fowler, F. J., Jr. (1995). Improving survey questions: Design and evaluation. Thousand Oaks, CA: Sage.

Gadbow, N. F. (2003). Teaching all learners as if they are special. In J. M. Ross-Gordon (Ed.), Contemporary Viewpoints on Teaching Adults Effectively (pp. 51-616). San Francisco, CA: Jossey-Bass.

Herrmann, A., Fox, R, \& Boyl, A. (2000 Winter). Learning technologies for learner service. In E.J. Burge (Ed.), The Strategic Use of Learning Technologies (pp.39-48). San Francisco, CA: Jossey-Bass.

Hilvitz, P. (2000). Federal policy construction: An examination of how functional behavior assessment became part of IDEA. Dissertation Abstracts International, 61(07), 2660A. (UMI No. 9980265)

Husson, W.J., \& Kennedy, T. (2003 Spring). Developing and maintaining accelerated degree program within traditional institutes. In R.J. Wlodkowski, \& C.E. Kasworm (Ed.), Accelerated Learning for Adults: The Promise and Practice of Intensive Education Formats (pp.51-62). San Francisco, CA: Jossey-Bass.

Johnson, J. A. (1997). An analysis of curriculum design in developing a doctor of philosophy program in aeronology. Unpublished doctoral dissertation, Bowling Green State University, Bowling Green

Karwin, T. J. (1973). Flying a learning center: Design and costs of an off-campus space for learning. Berkeley, CA: The Carnegie Commission on Higher Education.

Maxwell, J. A. (1996). Qualitative research design- An interactive approach. Thousand Oaks, CA: Sage.

Maykut, P., \& Morehouse, R. (1994). Beginning qualitative research: A philosophical and practical guide. Washington, DC: The Falmer Press.

Morgan, David L. (Ed.). (1993). Successful focus groups. Newbury Park, CA: Sage. 
Mott, V. W. (2000 Summer). Learning in professional practice. In V. W. Mott and B. J. Daley (Ed.), Chartering A Course for Continuing Professional Education: Reframing Professional Practice (pp.33-42). San Francisco, CA: Jossey-Bass.

Oppenheim, A. N. (1996). Questionnaire design, interviewing, and attitude measurement. New York: Pinter Publishers.

Phillips, M., \& Kelly, P. (2000 Winter). Learning technologies for learner service. In E.J. Burge (Ed.), The Strategic Use of Learning Technologies (pp.17-26). San Francisco, CA: Jossey-Bass.

Pratt, D. D. (2003). Good teaching: One size fits all? In J. M. Ross-Gordon (Ed.), Contemporary Viewpoints on Teaching Adults Effectively (pp.3-16). San Francisco, CA: Jossey-Bass.

Ray, R. L. (1997). The experience of high school teachers with a zero tolerance for fighting policy. Dissertation Abstracts International, 62(05), 1669A. (UMI No. 3013858)

Robinson, N. (1999). The use of focus group methodology - with selected examples from sexual health research. Journal of Advanced Nursing. 29 (4), 905-904.

Scott, P. A., \& Conrad, C. F. (1992). A critique of intensive courses and an agenda of research. In J.C. Smart (Ed.), Higher Education: Handbook of Theory and Research (pp. 411-459). New York: Agathon Press.

Scott, P.A. (2003 Spring). Attributes of high-quality intensive courses. In R.J. Wlodkowski, \& C.E. Kasworm (Ed.). Accelerated Learning for Adults: The Promise and Practice of Intensive Education Formats (pp.29-38). San Francisco, CA: Jossey-Bass.

Stein, D. S., \& Imel, S. (2002 Fall). Adult learning in community: Theme and threads. In D.S. Stein \& S. Imel (Ed.), Adult Learning in Community (pp.93-97). San Francisco, CA: Jossey-Bass.

Swenson, C. (2003 Spring). Accelerated and traditional formats: Using learning as a criterion for quality. Accelerated Learning for Adults: In R. J. Wlodkowsi and C. E. Kasworm, The Promises and Practices of Intensive Educational Format (pp.83-92). San Francisco, CA: Jossey-Bass.

Wlodkowski, R. J., \& Westover, T. N. (1999). Accelerated courses as a learning format for adults. Canadian Journal for the Study of Adult Education, 13(1), 1-20. 


\title{
APPENDIX
}

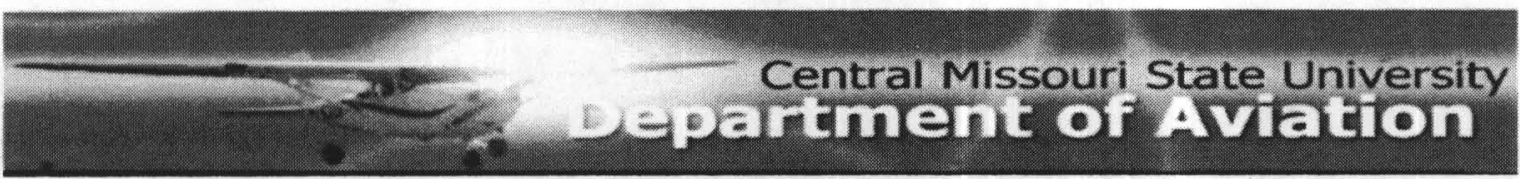

\author{
Central Missouri State University \\ Department of Aviation \\ T.R. Gaines 210
}

Warrensburg, MO 64093

January 27,2004

Dear Sir or Madam,

I am asking your help participate in a study regarding academic performance and teaching enhancement of off-campus aviation law class. By participating in this study, The aviation department is able to obtain your comments on the effectiveness of the offcampus aviation education. In the past decade, intensive format has become the mainstream mode for CMSU's off-campus aviation education. Nevertheless, there was no study pertaining to the discovery of learning outcome or teaching defectiveness that is critical for instructors to sharpen their teaching skills. To-date, while the Department of Aviation at CMSU is approaching its launch of a full-scale implementation of Internet-oriented education for future off-campus aviation students, your comments are indispensable to this regard.

The completion of this questionnaire and focus group discussion may take approximately 60 minutes. According to codes of ethics, your comments will remain extremely confidential. The results emanating from this study will be reported in general terms without reference to your particular contributions. The completion of the study will be available in about 2 months and you will receive a summary of the findings after data interpretation.

I hope you will participate in this study; but if for any reasons you decide to withdraw during the study, you are free to do so. I greatly appreciate your reply indicating that you are willing to participate in this study. I am looking forward to hearing from you soon. Thank you.

Sincerely,

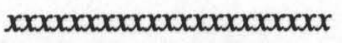

Department of Aviation

Central Missouri State University

T.R. Gaines 210c

Warrensburg, MO 64093; Tel: 660-543-8092; Email: ctlu@cmsul.cmsu.edu 


\section{QUESTIONNAIRE}

Survey - The Rationale of Taking Off-campus Aviation Classes

Introduction: The purpose of this survey is to provide a channel that allows you to help Department of Aviation enhance offcampus education. Based on your comments, the department is able to better serve prospective aviation students. For only research purpose, your comments will remain confidential and anonymous.

Part 1 - Please mark one that is most applicable to your status

1. Age: ___ (20-25), __ (26-35), __ (36-45), _ (45 and above)

2. Status: __ Graduate student, __ Undergraduate student

3. How many off-campus classes have you already taken?
(1-2),
$(3-4)$,
(5-6),
(7-8),

4. Does the class schedule properly meet your schedule?

Yes, No

5. What is the quality of this class?

Excellent, Good, Fair, __ Poor, Very poor

6. I have learned what I expected from this class? (Disagree) 12345678910 (Agree)

7. Are the following pedagogical techniques helpful to your understanding of aviation law?

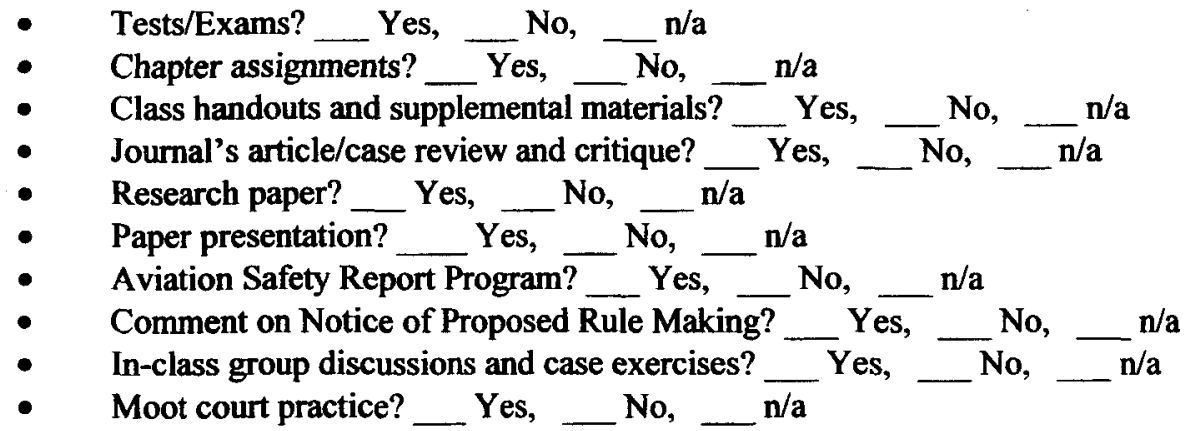

Any comments on this class? 


\section{Part II: Open-ended Questions (Focus Group Discussion)}

Instruction: In this section, we will provide several open-ended questions for focus group discussion. You are free to contribute any ideas/comments/opinions associated with each question.

Q1. What is(are) the purpose(-s) for you to study while working fulltime or part time? Please also provide a detailed example.

Q2. What is the rationale for you to take off-campus classes based on weekend intensive format? (e.g., schedule flexibility, cost, lower class workload, better teacher, etc.) Why? Example(-s)?

Q3. What can be done to enhance the current weekend intensive format education provided by CMSU? Why?

Q4. How do you value a totally Internet-base aviation (law) class? Why?

Q5. Per the question above, in your opinions, what should aviation department do to create a good learning environment for students based on a fully Internet-base education? 